\title{
Enhancing Critical Thinking Skills and Writing Skills through the Variation in Non-Traditional Writing Task
}

\author{
Parlindungan Sinaga \\ Dr., Indonesia University of Education, Indonesia, psinaga@upi.edu
}

Shelly Feranie

Indonesia University of Education, Indonesia

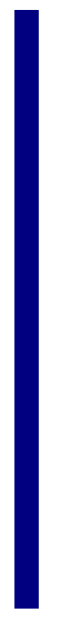

\begin{abstract}
The research aims to identify the impacts of embedding non-traditional writing tasks within the course of modern physics conducted to the students of Physics Education and Physics Study Programs. It employed a quasi-experimental method with the pretest-posttest control group design. The used instruments were tests on conceptual mastery, tests on critical thinking skills, and a rubric of writing assessment. The data were analyzed by determining the percentages of average normalized gains, Cohen's d, and correlational analysis. Based on the results of data analysis, it is found that the different treatments in the non-traditional writing tasks given to the students of the Physics Education and Physics Programs have the following impacts: 1 . There was a significant difference in the increased conceptual mastery and critical thinking skills; 2 . There was a difference in the writing quality of the students of the Physics Education and Physics Program; 3. There was a correlation between writing quality and conceptual mastery with a high degree relationship and there was a correlation between writing quality and critical thinking skills with a low degree relationship; 4. Increased conceptual understanding was influenced by the writing domain.
\end{abstract}

Key Words: critical thinking skill, quasi-experimental method, non-traditional writing tasks, conceptual mastery, writing to learn

\section{INTRODUCTION}

Writing is a part of teachers' and scientists' job to help them in memorizing, making reports, planning and regulating, encouraging critical thinking skills, self-reflection over conceptual mastery, and communicating. Writing is also a part of science, although many prospective scientists and pre-service teachers do not receive formal training in writing (Barrass, 2000). In the curricula of Indonesian teacher training and education institutes, writing knowledge and skills are only embedded within the course subjects of English and Indonesian, each with two credit hours. In the descriptions of the two courses, writing is only a subtopic among many other topics taught. Based on the

Citation: Sinaga, P. \& Feranie, S. (2017). Enhancing Critical Thinking Skills and Writing Skills through the Variation in Non-Traditional Writing Task. International Journal of Instruction, 10(2), 69-84. https://doi.org/10.12973/iji.2017.1025a 
interview with lecturers who teach the courses, obtained information that writing knowledge and skills are taught to students, but not optimally. The less than optimal teaching of writing has resulted in the low writing skills of pre-service teachers and future scientists. This was reinforced by one of the following fact: students are required to write articles research results and published by local journaling which is managed by the department of physical education. Each year there are 60 articles on average reviewed by editors, out of which only $27 \%$ of eligible. In addition, there is a lack of support for them to develop their writing skills. Thus, instructional strategies that can increase conceptual understanding as well as increasing the writing skills of pre-service teachers and prospective scientists are needed. Based on the facts, the strategy of writing to learn or writing in science embedded within various course subjects is the appropriate solution.

In the last three decades, the writing to learn strategy has put more stress on the use of non-traditional writing in science as a development of the role of traditional writing (Keys, 1999 a). Traditional writing refers to the use of writing in science teaching and learning for the purposes of communication and evaluation. However, the activity of traditional writing, such as taking notes from textbooks or taking notes during dictation probably cannot help students understand knowledge and communicate with others (Henderson \& Wellington, 1998; Keys, Hand, Prain \& Collin., 1999 b). In addition, this activity makes students passive and teaching and learning boring because it does not really engage students' mind (Henderson \& Wellington, 1998).

Meanwhile, non-traditional writing refers to the use of writing in science as a mode of learning through a number of various writing tasks, which is in line with the knowledgetransforming model (Bereiter \& Scardamalia, 1987). The relationship between student planning, writing and learning in science, and the number of writing tasks has been investigated by Hand, Hohenshell, and Prain (2004), and the results show that nontraditional writing activity helps promote students' conceptual understanding. They also have found that students who do more than one non-traditional writing task can work on conceptual questions better than those who only do one writing task.

Prain \& Hand (1996) proposed five elements to guide the learning of writing in science: writing type, writing purpose, audience, topic, and method of text production. Studies in general show that writing for authentic audiences in various formats increases students' engagement, helps students learn better, and increases satisfaction in the teaching and learning process (Hand, Yang, \& Bruxwoort, 2007; McDermoth \& Kuhn, 2011; Wallace, 2007; Gunel, Hand \& Mcdermott 2009). As a whole, the studies of Gunel, Hand, and McDermot (2009), Hand et al. (2007), McDermott \& Hand (2010), Kingir (2013), Atasoy (2015) indicate that students engaged in non-traditional writing for certain audiences can significantly increase their conceptual understanding and develop positive attitudes towards knowledge and writing, and the non-traditional writing helps them understand mix concepts.

The use of non-traditional writing tasks in science education is an area of research currently developing in the world. The types of writing such as writing self-explanations, making self-summary, or writing reports, enable students to apply newly gained 
concepts or ideas into different contexts. When writing individually or collaboratively, students can think critically and associate their understanding, both in social regulations and in the current scientific community knowledge (Keys, 1999 a; Keys et all, 1999 b). Consequently, they can build explanations and understand information from sources such as classroom discussion, laboratory, or textbooks. Based on this consideration, the research aims to broaden the area of this research into the part that has not been researched, namely to investigate the impacts of different non-traditional writing tasks in physics teaching and learning on students' increased critical thinking skills and writing quality, and to identify the relationship between students' writing quality and their critical thinking skills and conceptual understanding. The problem is formulated into the following research questions: 1) How does the conceptual understanding of the experimental and control class students increase? 2) How do the different treatments impact on increased conceptual understanding of each topic or domain? 3) How does the quality of students' writing differ between those of the experimental class and the control class? 4) How does writing quality correlate with conceptual understanding? 5) How do the critical thinking skills of the experimental and control class students increase? 6) How do the different treatments impact on the increased critical thinking skills of the experimental and control class students? 7) Does the writing domain influence the quality of the writing products?

The contributions of this article to the literature are: 1) Finding the extent to which increased critical thinking skills can be distinguished as an impact of different types of writing tasks, authentic audiences, and text production; 2) Identifying the correlation between the quality of writing and increased conceptual understanding for each domain and the correlation between the quality of writing and critical thinking skills.

\section{METHOD}

This study used a quasi-experimental research because researchers do not have the ability to randomly assign participants and/or ensure that the selected sample is homogenous as desired, and the limited ability to completely control all the variables and implications of treatment in the study group (Leedy \& Ormrod, 2010 ).

This study design involves two classes of students grouped into experimental group and control group, then chosed non-equivalent control group design with pre-test and posttest (Cohen, Manion, \& Morrison, 2007). Both group used direct instruction combined with writing to learn approach. Each class was given two writing tasks with different topics. The difference in the treatment of the experimental and control group lies on the writing tasks. The experimental group consisting of physics pre-service teachers was assigned to write subject material preparation for secondary students. The writing products would be used during their teaching practicum in secondary schools. Hence, the target audiences were secondary school students. The topics consisted of wave-particle properties of light and matter waves, adjusted to the secondary school physics curriculum. The control class was assigned to write a paper on concept explanation and its application in technology and daily life. The target audience was the 
lecturer teaching modern physics. The writing topics covered the wave-particle properties of light and matter waves.

Each topics of modern physics were taught in two meetings, with each meeting lasting for 4 x 50 minutes. The time allocated to do writing tasks was a week for each task. In the beginning of the course, a pretest of conceptual understanding was given, followed by teaching and learning, and then a writing task at the end of the course for both classes. In the subsequent meeting, before the teaching and learning of the second topic, each class was given a posttest of conceptual understanding of the first topic. The posttest for the second topic was given at the same time as the submission for the second writing task on the topic of matter waves. The pretest of critical thinking skills was administered in the beginning of the meetings for the first topic and the posttest was given at the end of the meetings for the second topic. To get good quality writing, at the end of the second meeting for the first topic, a lesson on how to write was embedded within the teaching and learning process. For the Physics Education Program students, the steps to write physics teaching materials were briefly taught, using the model of teaching material writing process (Sinaga, Suhandi.\& Liliasari . 2014). For the Physics Program students, they were briefly taught how to write a paper. The writing on the first topic was returned to each student after feedback was given.

The research instruments consisted of concept mastery test, critical thinking skill test, and writing assessment rubric. The concept mastery instrument included a concept mastery test on the subject of wave-particle properties of light and a concept mastery test on matter waves. Tests mastery of concepts in the form of multiple choice questions with a number of 20 questions, while tests of critical thinking skills in the form of multiple choice questions with a number of 10 questions, adapted from the work Ennis (1996). The validity of the instrument was evaluated using the Pearson product moment and Reliability instruments were evaluated using the Kuder-Richardson KR-21 (Arikunto, 2013) the correlation coefficient of each items for conceptual mastery of instruments ranging from 0.42 to 0.79 , and the coefficient of reliability tests 0.83 . While the correlation coefficient of each item instrument of critical thinking skills range between $0,41-0,88$ to test reliability coefficient of 0.89 Students' writing was assessed using a rubric of writing assessment. The elements assessed included: Concept accuracy, clarity of concept explanation (for example, whether the student uses multiple modes of representation or not), writing hierarchy, the breadth and depth of discussion, and the suitability of content to the writing form and target audience and to writing conventions.

\section{Data Analysis}

The increase in concept mastery and critical thinking skills was determined by calculating the normalized gains, and the gains were interpreted with Hake's criteria (1998). The analysis of the impacts of the different treatments on increased cognitive and critical thinking skills was carried out by calculating Cohen's d and interpreted against Cohen's criteria (Coe, 2000). To analyze the relationship between students' writing skills and cognitive as well as critical thinking skills, linear regression analysis was done (Sudjana, 2005). 


\section{Study Samples}

Samples are determined not to be based on strata, and not randomly, but based on their specific goals or called purposive sampling techniques (Arikunto, 2013). The subjects consisted of a total of 82 students enrolled in the modern physics course for the academic year of 2015-2016 in one of the state universities in Bandung, Indonesia. They are fourth semester second year student.They were divided into two classes, with 46 Physics Education Program students consisting of 16 male, 30 female and 36 Physics Program students consisting of 12 male and 24 female assigned to the experimental class and control class, respectively. Both classes were taught by the same lecturer.

\section{FINDINGS}

The first research question is about how the conceptual understanding of the experimental does and control classes increase before and after treatment. The results of the calculation of average normalized gains for the experimental and control classes are displayed in Table.1.

Table 1

Average normalized gains of conceptual understanding for each domain

\begin{tabular}{lllll}
\hline Domain & & posttest & pretest & $g$ \\
\hline Wave particle properties & Control & 50.28 & 26.24 & 0.19 \\
\cline { 2 - 5 } & Experimental & 78.12 & 29.42 & 0.69 \\
\hline Matter waves & Control & 60.76 & 38.22 & 0.36 \\
\cline { 2 - 5 } & Experimental & 74.86 & 37.57 & 0.59 \\
\hline
\end{tabular}

The second question is about how the different treatments impact on increased conceptual understanding for each domain. Its effect size was subsequently calculated, and the resulted Cohen's coefficient was interpreted using Cohen's criteria as displayed in Table 2.

Table 2

Effect Size for each domain

\begin{tabular}{lllll}
\hline Domain & Mean control & Mean Exp & STDEV pool & Cohen d \\
\hline Wave-particle properties & 24.02 & 48.70 & 26.47 & 0.93 \\
\hline Matter waves & 22.54 & 37.29 & 19.36 & 0.76 \\
\hline
\end{tabular}

The third question is about how the quality of the writing produced by the experimental and control class students is. Students' writing for the first and second assignments was evaluated using writing assessment rubric with a score ranging from $0-100$, in which the domains for the first and second assignments were wave-particle properties of light and matter waves, respectively. The average results of the experimental and control class students' writing task for each domain are presented in Table 3.

Table 3

The writing quality of the experimental and control class students for each domain

\begin{tabular}{llll}
\hline & Mean of Assignment 1 & Mean of Assignment 2 & Mean \\
\hline Experimental & 57.28 & 70.64 & 63.96 \\
\hline Control & 51.91 & 57.82 & 54.86 \\
\hline
\end{tabular}


The fourth question is about how the correlation between writing quality and conceptual understanding for each domain is. A correlation analysis was carried out to identify the degree of closeness between students' writing quality and their conceptual understanding for each domain. For the domain of wave-particle properties, a linearity test at the significance level of $\alpha=0.01$ was conducted, and the regression line between concept mastery and writing quality was found to be linear with $\mathrm{F}_{\mathrm{tc}}(0.68)<\mathrm{F}_{0.99(26 / 18)}=$ 2.96. Its correlation coefficient was 0.78 with a high category, while the coefficient determination between variables was 0.61 . For the domain of matter waves, $F_{t c c}=1.51$ and $F_{0.95(15 / 8)}=3.12$ with the level of significance $(\alpha)=0.05$. Because $F_{\mathrm{tc}}(1.54)<F_{0.95(15 / 8)}=3.12$, then it can be concluded that the regression equation was linear. The correlation coefficient was 0.65 with a high category and the coefficient determinant was 0.42 . Based on the findings, the writing quality of each writing type and domain strongly correlated with students' conceptual understanding.

The fifth research question is about how the critical thinking skills of the experimental and control class increase. The results of the calculation of average normalized gains are displayed in Table 4.

Table 4

Average Normalized Gains for critical thinking skills

\begin{tabular}{llll}
\hline & posttest & pretest & $g$ \\
\hline Control & 56.67 & 29.35 & 0.38 \\
\hline Experimental & 67.91 & 31.54 & 0.53 \\
\hline
\end{tabular}

The sixth research question is about how the different treatments impact on students' critical thinking skills. The impacts of the different treatments on increased critical thinking skills are shown in Table 5.

Table 5

Effect Size treatment on increased critical thinking skills

\begin{tabular}{llllll}
\hline Mean exp. & Mean cont. & STDEV exp. & STDEV Cont. & STDEV pool & Cohen's $d$ \\
\hline 36.37 & 27.32 & 7.83 & 14.62 & 11.81 & 0.93 \\
\hline
\end{tabular}

The seventh research question is about how students' writing quality correlates with critical thinking skills. Based on linearity test, $F_{\mathrm{tc}}=2.81$ and $F_{0.95[15 / 8)}=3.27$ with a level of significance $(\alpha)=0.05$. Hence, it can be concluded that there was a linear relationship between the variables of writing quality and critical thinking skills. The correlation coefficient $(r)=0.24$ and was included under the category of low level correlation with the value of coefficient determinant of 0.06. Based on the criteria of degree of closeness, it can be concluded that writing quality has a low level correlation to critical thinking skills.

\section{DISCUSSION}

The first research question is about how the conceptual understanding of the experimental and control class students' increases. The findings, as shown by table 1 , 
indicate that the conceptual understanding of the experimental class students increased for both topics, which was categorized as a medium increase. Meanwhile, the increased conceptual understanding in the control class for the topic of wave particle properties of light and matter waves was categorized under the category of low and medium, respectively. The second research question is intended to find whether there is a difference in the increased conceptual understanding as a result of different treatments between the experimental and control classes, and the extent to which the impacts can be differentiated or whether the difference is significant. The results of the calculation are presented in Table 2. It is clear that different treatments have different impacts on increased conceptual understanding of the control and experimental classes for each domain. The value of Cohen's $d$ for the topic of wave particle properties was categorized as high, while that of matter waves was medium. The findings of this research tend to be similar to those of previous research (Hand, Yang, \& Bruxwoort, 2007; McDermoth \& Kuhn, 2011; Wallace, 2007; Gunel, Hand, and McDermot, 2009; Gunel et all. 2009, Hand et all., 2007 b; McDermott \& Hand 2010; Kingir, 2013; Atasoy 2015). Nevertheless, this research adds a finding that the writing domains also have influence on the levels of increased conceptual understanding. The increased conceptual understanding for the topic of wave-particle properties of light as a result of different treatments differed greatly between the experimental class and control class, while that for the topic of matter waves differed moderately.

The variations in the non-traditional writing tasks in relation to the third and fourth research questions have successfully identified a difference in writing qualities and correlation between conceptual understanding and writing quality. The writing quality of the experimental and control class students experienced an increase from the first to the second writing task. One of the factors that have made the increase possible is feedback given to the first writing task. In terms of average grade of writing, the experimental class had a greater grade average than the control class. Another finding identified is that there was a linear correlation between students' writing quality and concept mastery, and the correlation was categorized as high, both for the domains of waveparticle properties of light and matter waves.

In relation to the fourth to the seventh research questions, the research has successfully found several facts. The variations in non-traditional writing task result in increased critical thinking skills. Based on Hake's criteria (1998), the average normalized gain for the experimental and control classes is the same, namely under the medium category. The effect size has helped identified that the impacts of variations in writing tasks between the experimental class and control class on increased critical thinking skills were significantly different, or the difference was under the high category. Another finding is that there was a linear correlation between writing quality and increased critical thinking skills, and the correlation coefficient was at the low level.

The factors that possibly have made differences in increased critical thinking skills, conceptual understanding, and writing qualities between the experimental and control classes can be traced from the variations in writing tasks. In this research, the writing task given to the experimental class was writing teaching materials for the preparation of 
pre-service teachers in taking the teaching practicum in secondary schools. The stages taken by these pre-service teachers in writing the teaching materials consisted of: 1) Analyzing physics curriculum for secondary school; 2) Determining the breadth and depth of the subject matter; 3) Determining the outline and hierarchy; 4) Making multiple representations for each concept covered in the subject matter; and 5) Writing a draft by combining the verbal and visual representations. The activities were formulated based on results of literature review of writing skill development. Graham (2006) noted that writing is a complex process, in which a good writer has to learn and master several different skills and strategies; for example, the special skills for actual writing process. A part of a writing task design is scaffolding to strengthen the habit of a prospective writer. In the perspective of instructional design, apart from the level of their education curriculum, students require structured tasks and deadlines (Guilford, 2001; Luttrel, Bufkin, Eastman \& Miller, 2010; Regan \& Pietrobon, 2010). Structured writing tasks are facilitated through multi-stage processes: Given the time limit for drafting, feedback from various perspectives, and opportunities for revision (Fisher, Gazza \& Hunker, 2012; Guilford, 2001; Luttrell et al., 2010; Regan \& Pietrobon, 2010). In addition, in order to be an effective writer, one requires knowledge about writing (for instance, target audiences, information about topics, etc.), and an effective writer needs to be motivated to write (Pajares, 2003).

In the first activity, students should read and study physics curriculum for senior high school, the topics of wave-particle properties of light and matter waves to be taught in the second semester of the eleventh grade of senior high school, and the core competencies and basic competencies that should be achieved by students in relation to the topics to write. In the second activity, students ought to learn about their target audiences, namely senior high school students. It is not guaranteed that their prior knowledge of the topics they gained from their previous modern physics course will be appropriate for secondary level. Hence, they would have to limit the breadth and depth of their writing based on the basic competencies found in the school curriculum. The next activity was for each student to plan the order of their writing, whether from the general to the specific, or vice versa. The correct outline with the correct order can only be made once the students understand the content. At this stage, students ought to reread and re-learn the topics of their writing, both from course notes and textbooks. Subsequently, they made concept maps, until finally they decided the content hierarchy of their writing.

After they had got a clear idea of the order of the writing, in the next activity students should plan how each concept or physics law covered in the writing would be represented. This activity will make them aware that although their target audiences are of the same level, each of them will have different reading abilities. Students' writing should be able to accommodate the different reading abilities. Thus, students must use multiple representations of concept, at least two modes of representation, namely verbal and visual modes (pictures or graphs or diagrams and the like). Explaining concepts using multiple representations has multiple merits, in which besides the produced writing is more easily understood by the audiences, the student writers will benefit from the representations. As put forward by Ainsworth, Prain, \& Tytler (2011), visual 
representation such as drawing or sketches is a form of language and a communicative tool that supports the process of meaning making. Furthermore, drawing and sketching make students' thoughts visible and play a significant role in developing students' creativity (McGrat \& Brown, 2005). Several studies in the writing to learn area with multiple representations (Atila et all,2010; Gunel, Hand, \& Gunduz, 2006; Hand, Gunel, \& Ulu, 2009; Sinaga, Suhandi \& Liliasari, 2015) used multimodal representations embedded in writing to learn activities in order to give benefits to the writers. Essentially, by assigning students to represent concepts with multiple representations, the students will be able to internalize their prior knowledge and the one they newly learned, train their creativity, and increase their critical thinking skills.

The fifth activity was to write a draft of teaching materials based on the outline made from the first to the fourth activities. At this stage, students should also pay attention to other things, such as put forward by Bailey (2003): Control over content, format, sentence, structure, vocabulary, punctuation, spelling, and writing formation; in other words, control at the sentence level. In addition, the writers should be able to formulate and integrate information cohesively and coherently in paragraphs and texts. Writing cannot be achieved when there is no coherence between words or sentences arranged in a certain order and connected in a certain way, and above all, it should be meaningful

The Physics Program students were assigned to write a paper. Each student was given this assignment twice, namely for the topics of wave-particle properties of light and matter waves, respectively. The first paper was to explain the concept of blackbody radiation, photoelectric effects, and x-rays, and their applications in technology and daily life. The second writing was concerned with explanations of matter waves and their application in the technology and daily life. The audience for both papers was the lecturer teaching the courses. The general format of the paper was determined by the lecturer, but the students were given freedom to be creative with their own writing.

The writing task given to the Physics Program students was different in terms of type of writing and audiences. After the students had gained knowledge about both topics from their courses, they had to process the content of each topic based on their own understanding. Subsequently, they had to transform the knowledge stored in their long term memory into their writing. The task on the first topic requires students to explain the physic phenomena, the experimental facts, and the theoretical explanations. They also had to explain in their papers the applications of this concept in technology and daily life. For instance, on the concept of photoelectric effects, students must explain how the phenomenon of photoelectric effect occurs, the experimental facts about the phenomenon, and then explain it theoretically. Besides, they had to explain the application of photoelectric effects, for example, in the technology of solar cells and how this technology is applied in daily life. Each student did a self-review of their own drafts, re-read their course notes, textbooks, and other sources to ensure that there was no misconception. They also edited and revised their writing until they finally became convinced that their papers were in accordance with the regulations.

The findings of this research demonstrate that the impacts of different treatments with variations in writing types, authentic audiences, and text production stages and domains, 
between the experimental and control classes have significantly different impacts on conceptual understanding. The factors causing this are possibly the many stages taken to write and the many activities in reviewing and editing. The writing preparation of the experimental class was done through reading and analyzing the secondary school curriculum; writing goals or indicators; writing content hierarchy plan, such as making concept maps; writing an outline; making multiple representations of the concepts covered; and making drafts. The writing stages enable students to plan their writing in detail and comprehensively. In addition, at every stage, students must review, read, and edit. Hence, the activities of reviewing, reading, and editing were more frequently done by the experimental than the control class. Besides, target audiences of the Physics Education Program students were secondary school students, thereby encouraging them to make their writing more easily read and understood by the audiences. To do so, the students explained the concepts through multiple representations. Each concept covered in the subject matter was explained by multiple representations. In order for the students to represent concepts in multiple modes, they have to understand the concept in-depth first. Meanwhile, the stages of writing a paper taken by the Physics Program studentsstarting from planning to text production-were not as complex as those taken by the pre-service program students. The fewer and less complex stages caused fewer activities of reviewing and editing. This is so because reviewing the accuracy of content is related to the activity of reading source texts. With fewer reviewing activities, the reading activities carried out by the Physics Program students become fewer as well. In addition, because the audience was the lecturer, the students were not burdened by the requirements of having their writing easily read and understood by their target readers. Based on this consideration, multiple representations were not really taken into account in their writing. It is these factors that cause a significant difference in the increased conceptual understanding between the experimental and control classes.

The findings of this research also show that there was a linear correlation between students' writing quality and conceptual understanding. Another finding to note is that the average writing grade of the Physics Education Program students was greater than that of the Physics Program students. One of the possible factors to this is the repeated reading activity carried out by the Education Program students during the review and editing of their writing. The activity of reading textbooks or other sources during writing preparation is linked to writing quality (Breetvelt, van den Bergh, \& Rijlaarsdam, 1996). These scholars stated that during drafting, reading can trigger other processes, such as planning (taking information from the long-term memory to make organization easier), translating to detect errors, or editing or reviewing the draft. The writer's ability to understand the source document determines his or her skill in integrating the information into his or her writing. Revising writing also depends on reading strategies. Based on these findings, there is a linear correlation between students' writing quality and conceptual understanding. The better students' conceptual understanding is, the better the writing products will be.

The research has also shown that variations in writing tasks had significantly different impacts on increased critical thinking skills, or the difference was categorized as high. In addition, it was also found that there was a linear correlation between writing quality 
and increased critical thinking skills. Educators agree that developing general thinking skills, especially critical thinking skills, is one of the main goals of education (Gelder, 2003). Physics teaching and learning in the course of modern physics through the implementation of non-traditional writing tasks can help realize this main goal of education. Ennis, H.R (in Crow \& Linda, 1989) defined critical thinking as reasonable, reflective thinking focused on deciding what to believe. Ennis also defined critical thinking as reflective thinking, which requires reflective activities and should be oriented to understanding the nature of a problem, not only solving the problem (Crow \& Linda, 1989). According to Cross et all. (2008), the writing to learn strategy is designed not only to involve the transmission of a series of facts that should be known by students, but to encourage students to engage in critically thinking about the concept of science, supporting claims using evidence, and justifying their ideas with practical explanations. The implementation of the writing to learn strategy in the modern physics course is focused on a certain set of pedagogical strategies that use writing not as a means of communication, but as way of encouraging critical thinking.

The specific abilities covered in the definition of critical thinking are: 1) analyzing arguments, claims, or evidence; 2) making inferences using inductive or deductive reasoning; 3) judging or evaluating; 4) making decisions or solving problems; and 5) asking and answering questions for clarification (Crow \& Linda, 1989). The five elements of critical thinking can be successfully evoked through non-traditional writing in science, ultimately for the type of writing teaching material preparations with secondary school students as the target audiences and modern physics as the topic.

At the stage of learning about secondary school physics curriculum, students should evaluate or assess the sub-topics to be covered and decide the breadth and depth of the teaching materials to be written. At the stage of reviewing drafts, students should recheck whether their drafts have been in accordance with the curriculum requirements and whether there are no misconceptions. Therefore, students must reread the sources to clarify any question popping out during self-review. Analyzing arguments claims or evidence also takes place when students are at the stage of reviewing their writing. Hence, these factors have caused an increase in critical thinking skills in the implementation of the writing to learn strategy. This finding is in line with Paul and Elder's statement (2008) that intellectual standards, clarity, logics, relevance, and content breadth and depth are the factors in designing writing task to promote critical thinking of the topics to write. Explicit feedback encourages students to move from learning on the surface learning to learning in depth, if strengthened by the logics of the concepts of critical thinking, relevance, breadth, and depth (Paul \& Elder, 2008).

\section{CONCLUSION}

Variations in non-traditional writing tasks which include writing types, authentic audiences, text production, and content given to the students of Physics Education and Physics Programs embedded within the course of modern physics have: 1) Successfully increased critical thinking skills, conceptual mastery, and quality of writing with significant differences in terms of levels of increases; 2) Shown that there is a strong correlation between writing quality and conceptual understanding, and there is a weak correlation between writing quality and critical thinking skills. 


\section{ACKNOWLEDGEMENT}

The writers would like to express their gratitude to the Ministry of Research, Technology, and Higher Education of the Republic of Indonesia for the research grant on which this research was funded.

\section{REFERENCES}

Ainswort, S., Prain,V., \& Tytler,R. (2011). Drawing to learn in science. Science, 333, 10961097.

Arikunto,S. (2013). Prosedur penelitian: suatu pendekatan praktik. Jakarta, PT Rineka Cipta.

Atila, M.E., Gunel, M., \& Buyukkasap, E. (2010) The effect of using different multi-modal representation within writing to learn activities on learning force and motion unit at midle school setting. Journal of Turkish Science Education, 7(4), 128- 133, ISSN: 1340-6020.

Atasoy, S. (2013). Effect of Writing to- Learn Strategy on Undergraduates Conceptual Understanding of Electrostatic. Asia Pasific Edu res,22(4), 593-602.

Bailey, S. (2003). Academic writing: a practical guide for students .Routledge Falmer.

Barrass, R. (2000). Scientist Must be Write, a guide tor better writing for scientists, engineers and students. E \& FN Spon, 11 New Fetter Lane, London.

Breetvelt, I., Van den Bergh, H., \& Rijlaarsdam, G. (1996). Rereading and generating and their relation to text quality. An application of multilevel analysis on writing process data. In G. Rijlaarsdam, H. van den Bergh, \& M. Couzijn (Eds.), Theories, models, and methodology in writing research (pp. 10-20). Amsterdam: Amsterdam University Press.

Bereiter,C.,\&Scardamalia,M.(1987). The psychologyof writen composition. Hillsdale, NJ:Lawrence Erlbaum

Coe, R (2000). What is an Effect Size?A Guide for User. Draft version.

Cohen, L., Manion, L., \& Morrison, K. (2007). Research methods in education. NewYork: Routledge

Cross, D., Taasoobshirazi, G., Hendricks, S., \& Hickey, D. T. (2008). Argumentation: a strategy for improving achievment and revealing scientific identities. International Journal Of Science Education 30, 837- 861.

Crow, Linda (1989). Enhancing critical thinking in the sciences society for college science teachers. Washington, DC.

Ennis, R.H.(1996). Critical Thinking. Prentice Hall Inc, Upper Saddle River, NJ 07458

Gazza, E. A., \& Hunker, D. F. (2012). Facilitating scholarly writer development: The writing scaffold. Nursing Forum, 47(4), 278-285.

Gelder, Tim van (2003). Teaching Critical Thinking: Lessons from Cognitive Science. Available: http://www.philosophy.unimelb.edu.au/reason/papers/Teaching_CT_Lessons.pdf.

Graham, S. (2006). Strategy instruction and the teaching of writing: A meta-analysis. In C. A. MacArthur, S. Graham, \& J. Fitzgerald (Eds.), Handbook of writing research (pp. 187207). New York: Guilford Press. 
Guilford, W. H. (2001). Teaching peer review and the process of scientific writing. Advances in Physiology Education, 25(3), 167-175.

Gunel, M., Hand, B., \& Mc Dermott, M.A. (2009). Writing for differences audiences: Effect on high school students' conceptual understanding of biology, Learning and Instruction, 19(4), 354-367.

Gunel, M., Hand, B., \& Gunduz, S. (2006). Comparing student understanding of quantum physics when embedding multimodal representation inti two diffrerent writing formats: Presentation format vs summary report format. Science Education, 90(6), 1092-1112.

Hake, R.R (1998). Interactive-engagement vs traditional methods: A six- thousand student survey of mechanics test data for introductory physics course. American Journal of Physics,66,64-74.

Hand,B., Hohenshell, I., \& Prain, V. (2004). Exploring student's responses to conceptual question when engaged with planned writing experiences: A study with year 10 science studen, Journal of Research in Science Teaching, 41(2), 186-210.

Hand, B., Yang, O.E., \& Bruxvoort,C. (2007). Using writing to learn science strategies to improve year 11 students' understanding of stoichiometry, International Journal of Science and Mathematics Education, 5, 125-143.

Hand, B. (2007). Cognitive, constructivist mechanism for learning science through writing. In C.S.Wallace, B. Hand, \& V. Prain (Eds), Writing and learning in the science classroom. Dordrecht, The Nederlands: Springer.

Hand,B., Gunel, M.,\& Ulu,C. (2009) Sequencing embedded multimodal representation in a writing to learn approach to the teaching electricity. Journal of Research in Science Teaching, 46(3), 225-247.

Henderson, J. and Wellington, J. (1998). Lowering the language barrier in learning and teaching Science. School Science Review, 79 (288), 35-46.

Keys, C. W. (1999a) Revitalizing writing in scientific genres: connecting knowledge production with writing to learn in Science. Science Education, 83, 115-130.

Keys, C. W., Hand, B., Prain, V. \& Collins, S. (1999b) Using the science writing heuristic as a tool for learning from laboratory investigations in secondary science Journal of Research in Science Teaching, 36(10), 1065-1084.

Kingir, H,S. (2013). Using no-traditional writing as a tool in learning chemistry, Eurasia Journal of mathematics, Science Technology Education, 9(2) 101-114.

Leedy, P. D., \& Ormrod, J. E. (2010). Practical research: Planning and design (9th ed.). Upper Saddle River, NJ: Prentice Hall.

Luttrell, V. R., Bufkin, J. L., Eastman, V. J., \& Miller, R.(2010). Teaching scientific writing: Measuring student learning in an intensive APA skills course. Teaching of Psychology, 37(3), 193-195.

McDermott, M.A., \& Kuhn, M. (2011). Using writing for alternatives audience in a college integrated science course, Journal of College Science Teaching 41(1), 40-45. 
McDermott, M.A., \& Hand, B. (2010). A secondary reanalysis of student perception of nontraditional writing task over a ten year period, Journal of Research in Science Teaching, 47(5), 518-539.

McGrath , M.B., \& Brown, J.R. (2005). Visual learning for science and engineering, Computer graphics and Application, IEEE, 25(5), 56-63.

Pajares, F. (2003). Self-efficacy beliefs, motivation, and achievement in writing: A review of the literature. Reading \& Writing Quarterly, 19, 139-158.

Paul, R., \& Elder, L. (2008). The thinker's guide to analytic thinking: How to take things apart and what to look for when you do (2nd ed.). Dillon Beach, CA: The Foundation for Critical Thinking.

Prain,V., \& Hand,B. (1996). Writing and Learning in secondary science: Rethinking practices. Teacher and Teacher Education, 12, 609-626.

Prain, V. (2007). The role of language in science learning and litearcy. In C.S.Wallace, B, Hand \& V. Prain (Eds), Writing and Learning in the science classroom, Dordrecht, The Nederland Springer.

Regan, M., \& Pietrobon, R. (2010). A conceptual framework for scientific writing in nursing. Journal of Nursing Education, 49(8), 437-443. http://dx.doi.org/10.3928/01484834-20100430-02.

Sinaga,P., Suhandi,A .,\& Liliasari. (2014). Improving the Ability of Writing Teaching Materials and Self-Regulation of Pre-Service Physics Teachers through Representational Approach, International Journal of Sciences: Basic and Applied Research, 15(1), 80-94.

Sinaga,P., Suhandi, A., \& Liliasari. (2015). The Effectiveness Of Scaffolding Design In Training Writing Skills And Improving Physics Conceptual Understanding: Preparing Preservice Physics Teachers To Be Novice Writers Teaching Materials, International Journal of Instruction , 8(1) 19-34.

Sudjana, S. (2005). Metode statistika edisi ke-6. Bandung : Tarsito.

Wallace, C.S. (2007). Evidence from the literature for writing as a mode of science learning. In C.S .Wallace,B. Hand \& V. Prain (Eds), Writing and Learning in the Science Classroom. Dordrecht, The Nederlands Springer.

\section{Turkish Abstract}

Geleneksel Olmayan Yazı Konularındaki Farklılıklarla Eleştirel Düşünme ve Yazma Becerisini Arttırmak

$\mathrm{Bu}$ araştırma, Fizik Eğitim Programlarının ve Fizik Çalışma Programlarındaki modern fizik eğitimi alan öğrencilerin modern fizik eğitiminde geleneksel olmayan yazma konularını kullanarak bunun etkilerini tanımlamayı amaçlamaktadır. Araştırma ön test son-test kontrol gruplu yarı deneysel yöntem ile desenlenmiştir. Veriler kavramsal bilgi düzeyi testi, eleştirel düşünme becerileri testi ve yazma değerlendirme anketi kullanılarak elde edilmiştir. Veri analizlerinin sonuçlarına göre Fizik Eğitiminde ve Fizik Programlarındaki öğrencilere verilen geleneksel olmayan yazma konularındaki farklı uygulamalar şu etkilere sahiptir: 1. kavramsal bilgi düzeyi ve eleştirel düşünme becerilerinde anlamlı bir artış elde edilmiştir. 2. Fizik Eğitimindeki ve Fizik Programındaki öğrencilerin yazma niteliklerinde anlamlı bir farklılık gözlenmiştir. 3. Yazı niteliği ve kavramsal bilgi düzeyi arasında yüksek oranda bir 
korelasyon;yazı niteliği ve eleştirel düşünme becerileri arasında düşük korelasyon saptanmıştır. 4. Artan kavramsal anlama düzeyi yazma alanından etkilenmiştir.

Anahtar Kelimeler: eleştirel düşünme becerisi, yarı deneysel yöntem, geleneksel olmayan yazma konuları, kavramsal bilgi düzeyi, yazmayı öğrenme

\section{French Abstract}

Amélioration de Compétences Pensantes Critiques et Compétences d'Écriture par la Variation dans Tâche d'Écriture Non traditionnelle

La recherche a pour but d'identifier les impacts de fixation des tâches d'écriture non traditionnelles dans le cours de physique moderne conduite aux étudiants d'Enseignement de Physique et des Programmes d'Étude de Physique. Il a employé une méthode quasi-expérimentale avec le design de groupe témoin pretest-posttest. Les instruments utilisés étaient des tests sur la maîtrise conceptuelle, des tests sur des compétences pensantes critiques et une rubrique d'écrire l'évaluation. Basé sur les résultats d'analyse de données, il est trouvé que les traitements différents dans les tâches d'écriture non traditionnelles données aux étudiants de l'Éducation de Physique et les Programmes de Physique ont les impacts suivant: 1. Il y avait une différence significative dans la maîtrise conceptuelle accrue et les compétences pensant critiques; 2 . Il y avait une différence dans la qualité d'écriture des étudiants de l'Éducation de Physique et le Programme de Physique; 3. Il y avait une corrélation entre l'écriture de la qualité et la maîtrise conceptuelle avec une haute relation de degré et il y avait une corrélation entre l'écriture de la qualité et des compétences pensant critiques avec une relation de degré basse; 4 . La compréhension conceptuelle accrue a été influencée par le domaine d'écriture.

Mots Clés: la compétence pensant critique, la méthode quasi-expérimentale, des tâches d'écriture non traditionnelles, la maîtrise conceptuelle, l'écriture pour apprendre

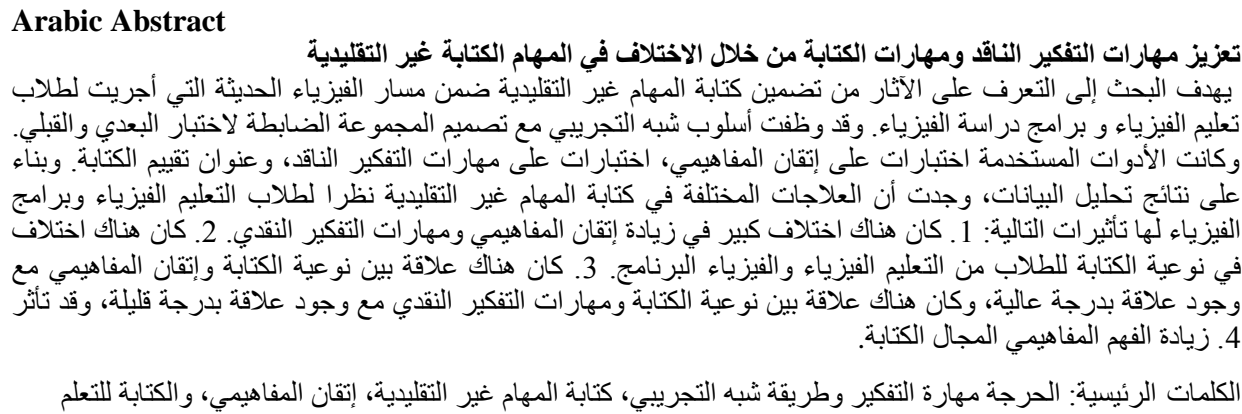

German Abstract

Verbesserung der kritischen Denken Fähigkeiten und Schreiben Fähigkeiten durch die Variation in nicht-traditionellen Schreiben Aufgabe

Die Forschung zielt darauf ab, die Auswirkungen der Einbettung von nicht-traditionellen Schreibaufgaben im Rahmen der modernen Physik zu den Studenten der Physik Ausbildung und Physik Studienprogramme durchgeführt zu identifizieren. Es verwendete eine quasiexperimentelle Methode mit dem Pretest-Posttest-Kontrollgruppen-Design. Die verwendeten Instrumente waren Testen auf konzeptionelle Beherrschung, Testen auf kritische Denkfähigkeiten und eine Rubrik der schriftlichen Bewertung. Basierend auf den Ergebnissen der Datenanalyse hat sich herausgestellt, dass die verschiedenen Behandlungen in den nichttraditionellen Schreibaufgaben, die den Studierenden der Physik- und Physikprogramme gegeben wurden, 1. Es 
gab einen signifikanten Unterschied in der erhöhten begrifflichen Beherrschung und kritischen Denkfähigkeiten; 2. Es gab einen Unterschied in der Schreibqualität der Studenten des PhysikBildungs- und Physik-Programms; 3. Es gab eine Korrelation zwischen Schreibqualität und konzeptioneller Beherrschung mit einem hohen Grad Beziehung und es gab einen Zusammenhang zwischen Schreibqualität und kritischen Denkfähigkeiten mit einem niedrigen Grad Beziehung; 4. Das zunehmende Konzeptverständnis wurde durch die Schreibdomäne beeinflusst.

Schlüsselwörter: kritische Denkfähigkeit, quasi-experimentelle Methode, nicht-traditionelle Schreibaufgaben, konzeptionelle Meisterschaft, Schreiben zu lernen

\section{Malaysian Abstract \\ Meningkatkan Kemahiran Pemikiran Kritis dan Kemahiran Menulis melalui Variasi dalam Tugasan Menulis Bukan Tradisional}

Kajian ini bertujuan untuk mengenal pasti kesan menerapkan tugasan penulisan bukan tradisional dalam fizik moden yang dijalankan untuk pelajar-pelajar Fizik Pendidikan dan Program Kajian Fizik. Kajian menggunakan kaedah kuasi-eksperimen dengan ujian pra-pasca reka bentuk kumpulan kawalan. Instrumen yang digunakan ialah ujian ke atas penguasaan konsep, ujian kemahiran pemikiran kritikal dan rubrik taksiran penulisan. Berdasarkan hasil analisis data, didapati bahawa rawatan yang berbeza dalam tugasan penulisan bukan tradisional yang diberikan kepada pelajar-pelajar Pendidikan Fizik dan Program Kajian Fizik mempunyai kesan berikut: 1 . Terdapat perbezaan yang signifikan dalam penguasaan konsep peningkatan dan kemahiran pemikiran kritikal; 2. Terdapat perbezaan secara bertulis kualiti daripada pelajar Pendidikan Fizik dan Program Fizik; 3. Terdapat korelasi antara kualiti penulisan dan penguasaan konsep dengan hubungan yang tinggi dan terdapat hubungan antara kualiti penulisan dan kemahiran pemikiran kritikal dengan hubungan tahap yang rendah; 4. pemahaman konsep Peningkatan dipengaruhi oleh domain penulisan.

Kata Kunci: kemahiran pemikiran kritikal, kuasi-eksperimen kaedah, tugas-tugas penulisan bukan tradisional, penguasaan konsep, menulis untuk belajar

\section{Russian Abstract}

Повышение Навыков Критического Мышления и Навыков Письменной Речи Путем Вариации Нетрадиционных Навыков Письменной Речи

Исследования, направленные на выявление воздействия внедрения нетрадиционных написаний задач в рамках курса современной физики привела студентов физиков к исследованию физики образования. Это использовало квази-экспериментальный метод с предварительным тестом, пост-тест группа управления дизайном. Использовались инструменты: тесты по концептуальному мастерству, тесты на навыки критического мышления и рубрика письменной оценки. На основании результатов анализа данных, найдено, что различные обработки в нетрадиционных письменных заданиях, данные студентам программы образования по физике оказывают следующее воздействие: 1 . Существовала значительная разница в увеличении концептуального мастерства и навыков критического мышления; 2. Существовала разница в письменных качествах студентов программы физического воспитания и физики; 3. Там была корреляция между качеством письма и концептуальным мастерством с высокой степенью взаимосвязи и там была корреляция между качеством письма и навыками критического мышления с низким уровнем отношений; 4. Возросшее концептуальное понимание было под влиянием домена письменности.

Ключевые Слова: умение критически мыслить, квази-экспериментальный метод, нетрадиционные письменные задания, концептуальное мастерство, писать, чтобы учиться 